3 Waterway Ecosystem Research Group, School of Ecosystem and Forest Science, University

4 of Melbourne, Burnley VIC 3121 Australia.

$5 \quad *$ Correspondence to: $\underline{\text { kathryn.russell@unimelb.edu.au }}$

$6 \quad$ Published article: https://doi.org/10.1016/j.earscirev.2017.04.001

$7 \quad$ Earth-Science Reviews 168 (2017) 73-80

$8 \quad$ Received 17 June 2016; Received in revised form 28 March 2017; Accepted 3 April 2017

$9 \quad$ Author-accepted version shared under CC-BY-NC-ND

\section{Global sediment yields from urban and urbanizing watersheds}

\author{
Kathryn L. Russell*, Geoff J. Vietz, Tim D. Fletcher
}

0

Abstract

Streams with urban watersheds are almost universally subject to degradation, largely driven

by changes to flow and sediment inputs from the watershed. However, the impact of

urbanization on sediment yields of urban watersheds is poorly understood. We undertook a

comprehensive review of global responses of fine-grained and coarse-grained sediment yields to different phases of urbanization and compared them to a long-standing conceptual model. The summarized yields showed a great deal of variability, but were consistent with the widely-used conceptual model for watersheds with active construction. Importantly, however, the yields for established urban areas tended to be higher than previously assumed, and tended to remain higher than background levels. This is most likely because 
21 the urban drainage network has a very high sediment transport efficiency and because the

22 increased runoff in urban watersheds is very effective at eroding the available sediment

23 sources (mainly infill development, urban decay and renewal, and gravel surfaces in parks

24 and gardens). The updated model provided here will assist in informing the extent to which

25 sediment supply to stormwater drainage systems and urban streams needs to be addressed

26 to assist the protection and restoration of streams in urban watersheds.

27 Keywords: Sediment yield; urbanization; urban streams; urban watersheds; stormwater

28 drainage; river management

\section{Introduction}

30 In our rapidly urbanizing societies, urban streams are becoming increasingly valued for the

31 products and services they provide to humans (fresh water, food, waste disposal), as well as

32 their intrinsic and biodiversity values. However, they are subject to extensive and severe

33 impacts from human use and land use changes, a problem that is encountered globally and

34 known as 'the urban stream syndrome'(Walsh et al., 2005a). With more than half the

35 world's population now living in urban areas, and with urban populations growing at $2.1 \%$

36 per year (The World Bank, 2014), the degradation of waterways through urbanization has

37 never been greater. Stream restoration is now a multi-billion dollar effort worldwide, with

38 the cost of stream restoration in the US alone exceeding a billion U.S. dollars a year

39 (Palmer et al., 2007).

40 It has long been recognized that channel morphology is a function of discharge and

41 sediment supply (Mackin, 1948). In the context of urban development, flow regime

42 disturbance has been widely studied as a key driver of the degradation of streams (Booth, 
43 1991; Hammer, 1972; Wolman, 1967), and the role of sediment regime change is receiving

44 increased recognition (Fletcher et al., 2014; O’Driscoll et al., 2010; Vietz et al., 2016; Vietz

45 et al., 2015; Wohl et al., 2015). This dual disturbance of both the flow and sediment regime

46 is analogous to the role of dams in sediment trapping and channel change that has been well

47 understood for several decades (Petts and Gurnell, 2005).

48 The prevailing and widely-used model of sediment supply from urban watersheds is based

49 on the 'cycle of urbanization' (Fig.1) proposed 50 years ago by Wolman (1967). The three

50 stages described include: a stable or equilibrium condition waterway with a forested or

51 agricultural watershed and modest sediment yields; a period of construction, when bare soil

52 is exposed and sediment yield rapidly rises, and a final stage where the watershed is

53 dominated by urban land cover, streams are stabilized and buried in pipes, and sediment

54 yield further declines to values as low as or lower than in the initial equilibrium stream.

55 The sediment response under established urbanization was represented with particular

56 uncertainty as indicated by the dashed line. Uncertainty was also indicated for forest yields,

57 highlighting the difficulty of measuring or inferring pre-agricultural conditions in areas

58 with a long history of agricultural development, which made early sediment yield

59 assessments difficult. 


\section{SCHEMATIC SEQUENCE: LAND USE, SEDIMENT YIELD \\ AND CHANNEL RESPONSE \\ FROM A FIXED AREA}

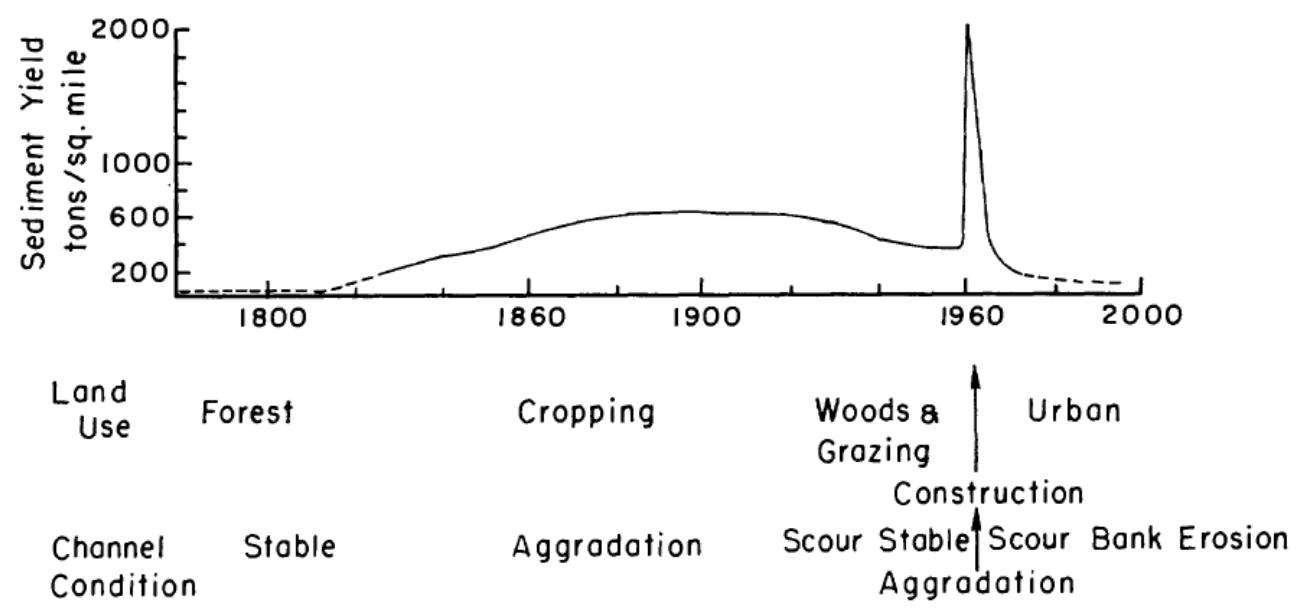

61 Fig. 1. Cycle of land-use change, sediment yield and channel behavior (reproduced from Wolman, 1967)

63 Very little work has tested or built on this conceptual model, despite recognition of the

64 impact of sediment regime disturbance on morphology and condition of streams in urban

65 watersheds (Bledsoe and Watson, 2001; Chin, 2006; Paul and Meyer, 2001; Vietz et al.,

66 2014). In particular, studies of sediment regimes of established urban watersheds are

67 limited (Chin, 2006). Urbanization impacts on sediment load are highly variable (Vietz et

68 al., 2015), and the question of whether there is a globally 'common' response is yet to be

69 thoroughly investigated.

70 Opportunities for addressing the 'urban stream syndrome' (Walsh et al., 2005b) are greatly

71 limited without understanding sediment supply from urban watersheds. Stream

72 characteristics such as bed complexity, hydraulic diversity and the presence of bars and 
73 benches, for example, are reliant on sediment and these characteristics, in turn, contribute

74 to the ecological condition of streams. Better understanding sediment supply to streams in

75 urban watersheds may reveal the need for management measures that consider sediment

76 regime restoration alongside activities that address flow regime and water quality (Vietz et

77 al., 2014; Wohl et al., 2015).

78 Scope of Review

79 Measured sediment yields from almost fifty published studies were summarized across a

80 range of urban and non-urban land-uses. This information is provided as Table $\mathrm{S} 1$ in the

81 supplementary material. We first summarized background yields, covering forested and

82 agricultural watersheds, to provide an indication of watershed yields prior to the initiation

83 of urbanization. Secondly, we collated sediment yields from newly urbanizing watersheds

84 and those undergoing construction, and where available, reported increases over

85 background yields. Finally, sediment yields from established urban watersheds were

86 summarized. Increases over background levels were included in the review either where

87 they had been directly reported in the literature, or where yields had been reported in

88 nearby forested or agricultural watersheds in either the same study or a different study in

89 the same location.

90 Where possible, the caliber of the sediment being investigated by each study was identified,

91 to capture any differences between responses of suspended and bedload sediment. The

92 distinction is crucial as suspended (fine-grained) sediments and bedload (coarse-grained)

93 sediments are transported by different mechanisms (Ackers and White, 1973) and play

94 different roles in the water quality, habitat and overall health of streams and receiving 
waters. Fine-grained sediments are often considered a pollutant, increasing turbidity, smothering habitat and rapidly carrying adsorbed nutrients and other contaminants to receiving waters (Houshmand et al., 2014; Owens et al., 2005; Taylor and Owens, 2009;

98 Vaze and Chiew, 2004), with consequent deleterious impacts on stream biota (Wood and 99 Armitage, 1997). In contrast, coarse-grained sediments play an important and immediate 100 role in maintaining the geomorphic condition and ecological health of waterways (Hawley 101 and Vietz, 2016).

102 While there is no agreed size classification for fine-grained versus coarse-grained sediment, 103 in general, we refer to sediment particles with diameters greater than $0.5 \mathrm{~mm}$ (coarse104 grained sand and greater (Wentworth, 1922)) as "coarse-grained" and particles with 105 diameters smaller than $0.5 \mathrm{~mm}$ (medium-grained sand and smaller) as "fine-grained". 106 Observations from suspended sediment sampling methods that do not report particle size 107 have all been classified as fine-grained sediment.

108 The distribution of studies reviewed, classified by type of sediment, land use and study 109 location, is shown in Table 1. Approximately half the studies were based in the United 110 States, and the majority of those were in the Eastern states, with a particular focus on the 111 Piedmont region. Over half the studies (and 79\% of data points) measured only suspended 112 sediment and another third measured total load (16\% of data points). Only nine studies (5\% 113 of data points) included measurements of bedload. A bias towards small watersheds was 114 also noted, with half the studies on watersheds smaller than 10 square kilometers.

115 Summary statistics for the collated sediment yield data is presented in Table 2 (suspended 116 and total yield) and Table 3 (bedload yield). 
117 Table 1. Number of studies and data points collated, by type of sediment, land use category

118 and location.

\begin{tabular}{|c|c|c|c|c|}
\hline & \multicolumn{2}{|c|}{ Sediment yield } & \multicolumn{2}{|c|}{ Increase over background } \\
\hline & $\begin{array}{c}\begin{array}{c}\text { No. of } \\
\text { studies }\end{array} \\
\end{array}$ & $\begin{array}{c}\text { No. of data } \\
\text { points }\end{array}$ & $\begin{array}{c}\text { No. of } \\
\text { studies }\end{array}$ & $\begin{array}{c}\text { No. of data } \\
\text { points }\end{array}$ \\
\hline All data & 48 & 334 & 26 & 187 \\
\hline Suspended and total load data & 43 & 322 & 26 & 187 \\
\hline \multicolumn{5}{|l|}{ By land use category: } \\
\hline Forest & 16 & 55 & - & - \\
\hline Agriculture & 21 & 181 & 7 & 109 \\
\hline Construction & 21 & 64 & 19 & 57 \\
\hline Urban & 13 & 22 & 12 & 21 \\
\hline \multicolumn{5}{|l|}{ By location: } \\
\hline $\begin{array}{l}\text { Americas (USA, Canada, } \\
\text { Brazil) }\end{array}$ & 24 & 146 & 15 & 84 \\
\hline Europe (UK) & 6 & 8 & 2 & 3 \\
\hline Asia (Malaysia, Japan, Israel) & 7 & 21 & 5 & 11 \\
\hline Africa (Kenya) & 1 & 61 & 1 & 57 \\
\hline $\begin{array}{l}\text { Oceania (Australia, NZ, } \\
\text { Tahiti) }\end{array}$ & 5 & 86 & 3 & 32 \\
\hline Bed load data & 9 & 17 & 0 & 0 \\
\hline \multicolumn{5}{|l|}{ By land use category: } \\
\hline Forest & 6 & 13 & - & - \\
\hline Agriculture & 3 & 3 & 0 & 0 \\
\hline Construction & 0 & 0 & 0 & 0 \\
\hline Urban & 1 & 1 & 0 & 0 \\
\hline \multicolumn{5}{|l|}{ By location: } \\
\hline Americas (USA, Canada) & 2 & 2 & 0 & 0 \\
\hline Europe (UK) & 2 & 3 & 0 & 0 \\
\hline Asia (Japan, Israel) & 2 & 4 & 0 & 0 \\
\hline Oceania (Australia) & 3 & 8 & 0 & 0 \\
\hline
\end{tabular}


Table 2. Summary statistics from collated data, suspended and total sediment yield

\begin{tabular}{|c|c|c|c|c|c|c|c|c|c|c|c|c|}
\hline \multirow{2}{*}{$\begin{array}{l}\text { Land use } \\
\text { category }\end{array}$} & \multicolumn{6}{|c|}{ Suspended/total yield $\left(\mathrm{t} / \mathrm{km}^{2} / \mathrm{yr}\right)$} & \multicolumn{6}{|c|}{ Increase over background (factor) } \\
\hline & $\begin{array}{c}\text { Sampl } \\
\text { e size }\end{array}$ & $\begin{array}{l}5 \\
\% \\
\end{array}$ & $\begin{array}{l}25 \\
\% \\
\end{array}$ & $\begin{array}{c}\text { Media } \\
\mathbf{n} \\
\end{array}$ & $75 \%$ & $95 \%$ & $\begin{array}{c}\text { Sampl } \\
\text { e size }\end{array}$ & $\begin{array}{l}5 \\
\% \\
\end{array}$ & $\begin{array}{l}25 \\
\% \\
\end{array}$ & $\begin{array}{c}\text { Media } \\
\mathbf{n}\end{array}$ & $\begin{array}{l}75 \\
\% \\
\end{array}$ & $\begin{array}{l}95 \\
\% \\
\end{array}$ \\
\hline Forest & 55 & 0.8 & 3.9 & 6.2 & 54 & 370 & & & & & & \\
\hline Agriculture & 181 & 10 & 40 & 90 & 238 & 1,627 & 109 & - & 1.6 & 3.2 & 9.0 & 68 \\
\hline $\begin{array}{c}\text { Constructio } \\
\mathbf{n} \\
\end{array}$ & 64 & $\begin{array}{c}11 \\
5 \\
\end{array}$ & 309 & 737 & 2,267 & 27,300 & $57 *$ & 3.0 & 7.5 & 16 & 64 & 419 \\
\hline \multicolumn{7}{|c|}{ Increase over forest yield } & $24 *$ & 5.9 & 13 & 56 & 101 & 353 \\
\hline \multicolumn{7}{|c|}{ Increase over agricultural yield } & $29 *$ & 1.8 & 5.1 & 11 & 30 & 535 \\
\hline $\begin{array}{c}\text { Constructio } \\
\text { n (fully } \\
\text { disturbed } \\
\text { sites only)*** } \\
\end{array}$ & 34 & $\begin{array}{c}31 \\
1\end{array}$ & $\begin{array}{c}278 \\
8\end{array}$ & 5,287 & $\begin{array}{c}12,66 \\
9\end{array}$ & $\begin{array}{c}189,52 \\
5\end{array}$ & $27 *$ & 20 & 230 & 544 & 845 & $\begin{array}{c}317 \\
0\end{array}$ \\
\hline \multicolumn{7}{|c|}{ Increase over forest yield } & $20 *$ & 54 & 430 & 675 & 931 & $\begin{array}{c}321 \\
2 \\
\end{array}$ \\
\hline \multicolumn{7}{|c|}{ Increase over agricultural yield } & $6^{*}$ & & 24 & 45 & 463 & \\
\hline Urban & 22 & 7.1 & 57 & 240 & 501 & 1,685 & 21 & 1.7 & 2.6 & 5.0 & 14 & 68.1 \\
\hline \multicolumn{7}{|c|}{ Increase over forest yield } & 13 & & 3.8 & 5.5 & 17 & \\
\hline \multicolumn{7}{|c|}{ Increase over agricultural yield } & 8 & & 2.1 & 2.9 & 8.0 & \\
\hline
\end{tabular}

124 Table 3. Summary statistics from collated data, bedload sediment yield. No estimates of

125 increase over background were available. Caution should be used making comparisons

126 between summary statistics for different land uses due to low sample sizes and different

127 locations of measurements in the different land use categories.

\begin{tabular}{ccccc}
\hline Land use category & \multicolumn{4}{c}{ Bedload yield (t/km $\mathbf{2} \mathbf{y r})$} \\
\cline { 2 - 5 } & Sample size & $\mathbf{2 5 \%}$ & Median & $\mathbf{7 5 \%}$ \\
\cline { 2 - 5 } Forest & 13 & 0.6 & 1.8 & 8.2 \\
\hline Agriculture & 3 & 10 & 15 & 39 \\
\hline Construction & 0 & - & - & - \\
\hline Urban & 1 & - & 6.3 & - \\
\hline
\end{tabular}




\section{Background Fine-grained Sediment Yields}

130 In order to assess the influence of urbanization on sediment yields, comparisons must be

131 made with background rates from undisturbed and agricultural watersheds. Suspended

132 sediment yields depend primarily on climate, land use, geology, soil type and position in a

133 watershed. Observed sediment loads rarely reflect 'intact' conditions and yields measured

134 in rural (agricultural) areas or managed forests will reflect a system that has already

135 adjusted (or is still adjusting) to some level of disturbance. However, it is still useful to

136 consider both undisturbed and agricultural land use as the "background" against which

137 urbanization occurs, due to the variation in pre-urban watershed condition worldwide.

138 Agricultural areas tend to have suspended sediment yields that are larger than comparable

139 forested watersheds (up to 70 times higher with a median increase of 3 times), but vary

140 greatly depending on the degree of disturbance (in turn linked to the type of agriculture)

141 and soil conservation practices (Wolman and Schick, 1967), as well as climate.

142 The summarized results of published work reveal that the majority of reported yields of

143 suspended sediment from forest areas fall in the range of $1-370 \mathrm{t} / \mathrm{km}^{2} / \mathrm{yr}$, with a median of

144 around $6 \mathrm{t} / \mathrm{km}^{2} / \mathrm{yr}$ (see Table 2). Yields from agricultural areas fall in the range of 10-1,600

$145 \mathrm{t} / \mathrm{km}^{2} / \mathrm{yr}$, with a median of around $90 \mathrm{t} / \mathrm{km}^{2} / \mathrm{yr}$. Background rates of suspended sediment

146 supply from forested watersheds are remarkably consistent in temperate forested areas,

147 ranging from 2-144 (median 7) t/ $\mathrm{km}^{2} / \mathrm{yr}$ for eastern USA, and 0.5-25 (median 5) t/ $/ \mathrm{km}^{2} / \mathrm{yr}$

148 for Eastern Australia. Agricultural and mixed watershed yields, however, tend to be

149 significantly lower for the older landscapes of Australia, with a median yield of 14

$150 \mathrm{t} / \mathrm{km}^{2} / \mathrm{yr}$, than the USA, with a median yield of $113 \mathrm{t} / \mathrm{km}^{2} / \mathrm{yr}$. 
151 New Zealand's South Island, with its high rainfall and steep, erodible watersheds, has some

152 of the highest recorded background sediment yields, reaching over $17,000 \mathrm{t} / \mathrm{km}^{2} / \mathrm{yr}$ in the

153 wettest areas (Griffiths, 1981). Fine sediment yields from forests in the Pacific Northwest

154 USA (Nelson and Booth, 2002) are also higher than typical forest yields. These elevated

155 values can be attributed to high relief and rainfall in these areas, but the extremely high

156 values in logging areas may be more influenced by forestry practices which can produce

157 large amounts of sediment (Croke and Hairsine, 2006).

158 Lake and reservoir sediment studies reveal the temporal changes in a single watershed over

159 a long time period, showing the impact of changing agricultural practices. For example,

160 studies of lake sedimentation in agricultural watersheds in the UK have found four to eight-

161 fold increases in total sediment load due to agricultural intensification and hedgerow

162 removal (Dearing et al., 1981; Foster et al., 1986; Foster and Walling, 1994). In contrast,

163 improved soil conservation practices can result in a decrease in agricultural fine sediment

164 yield over time, for example the decline to half to one third of the previous rate observed in

165 two reservoirs in Maryland (Holeman, 1965).

\section{Background Coarse-grained Sediment Yields}

167 While data on fine-grained sediment yield is plentiful in many regions due to good

168 coverage of suspended sediment sampling stations, bedload is rarely directly measured or

169 included in reported sediment load values (Milliman and Syvitski, 1992; Wohl et al., 2015).

170 Most commonly bedload is assumed to be approximately $10 \%$ of the total load (Dunne,

171 1979; Milliman and Meade, 1983; Nelson and Booth, 2002). This value is generally within 
172 the level of uncertainty of total load estimates (Dunne, 1979) and bedload is commonly 173 ignored.

174 A small number of studies have directly measured bedload yield from forested and 175 agricultural watersheds, either through reservoir sedimentation surveys or in-stream 176 bedload traps. Coarse-grained sediment (sand and gravel) yield has been estimated in small 177 forested watersheds of the mid-Atlantic piedmont to be $5-22 \mathrm{t} / \mathrm{km}^{2} / \mathrm{yr}$ (Smith and Wilcock, 178 2015), although some of the finer sand could have been transported as suspended load.

179 Bedload measurements in fire-disturbed and secondary forests in Japan (Nishimune et al., 180 2003) also fit within this range, whereas those reported in the older landscapes of south181 eastern Australia are generally lower, ranging from $0.5-5 \mathrm{t} / \mathrm{km}^{2} / \mathrm{yr}$ (Noske et al., 2010; 182 Papworth et al., 1990; Wu et al., 1984). Bedload from forested watersheds in the UK has 183 been found to be very low (0.003-0.004 t/ $\left.\mathrm{km}^{2} / \mathrm{yr}\right)$ (Foster et al., 1985). Coarse-grained 184 sediment yield from agricultural watersheds tends to be higher than comparable forested 185 watersheds, for example in the mid-Atlantic piedmont (Smith and Wilcock, 2015) and the 186 UK (Foster and Walling, 1994).

187 The bedload yield is highly dependent on the watershed setting and position within the 188 watershed, with larger sediment delivery ratios for coarse-grained sediments relative to 189 fine-grained sediments (Walling, 1983). Montane and smaller streams tend to have a 190 greater sediment yield and also carry a greater proportion of their load as bedload, while 191 lowland alluvial streams carry less total sediment, but proportionally more suspended load 192 (Milliman and Syvitski, 1992). This is illustrated by a study of a glacial stream in western 193 Canada, where bedload was estimated to account for around 50\% of the total load (Schiefer 
et al., 2010), a proportion much higher than estimated worldwide averages. Watershed

195 physiography makes it difficult to generalize background bedload sediment generation or

196 transport rates, even within a single basin.

\section{Fine-grained Sediment Yields from Urban Construction}

198 Newly urbanizing watersheds are subject to high rates of active construction, which

199 generate large amounts of sediment. Summarized suspended sediment yields from

200 urbanizing watersheds mostly fall within the range $120-27,000 \mathrm{t} / \mathrm{km}^{2} / \mathrm{yr}$, with a median of

$201740 \mathrm{t} / \mathrm{km}^{2} / \mathrm{yr}$. These yields tend to be 3-420 times higher than background rates, with a

202 median increase of around 60 times forest yields and 11 times agricultural yields.

203 Fine-grained sediment yields measured or computed at the scale of the active construction 204 zone range can be 21-12,000 times higher than background rates, and up to 20,000 times

205 higher in one observed case of an abandoned construction site in Malaysia (Leigh, 1982).

206 The median increase is around 700 times forest yields and 50 times agricultural background 207 yields when measured at this intensive scale.

208 Sediment load increases with the intensity of construction in the watershed, but there is 209 considerable variation between watersheds with similar levels of construction. In studies 210 reporting loads from 'fully disturbed' or similarly described watersheds (i.e. near $100 \%$ of 211 the site disturbed), there is variation of around 3 orders of magnitude, although this may be 212 partly due to differences in the definition of 'fully disturbed'. While sediment yield within a 213 basin is strongly related to the percentage of area under construction, there are significant 214 differences in the relationship between basins (Yorke and Herb, 1978). Construction site 215 slope, and the degree of sediment control were found to be significant factors as well as, to 
216 a lesser extent, proximity of construction to stream channels and presence of vegetated

217 riparian buffer zones (Yorke and Herb, 1978).

218 Coarse-grained Sediment Yields from Urban Construction

219 No studies were found which explicitly measure the coarse fraction of sediment output

220 from construction areas. Depending on the local setting, sediment provided by construction

221 areas (generally limited to sand-sized and smaller material (Graf, 1975)) may contribute to

222 bed material and bedload in streams, and can cause large sand slugs and clogging of the

223 channel with coarse-grained sediment (Guy, 1970; Wolman and Schick, 1967). Sand was

224 found to comprise $5-12 \%$ of the total sediment yield from a construction area in the USA

225 (Guy, 1974). In one case it was estimated that approximately one third of material removed

226 from the construction site was deposited in the stream channel (Wolman and Schick, 1967).

227 Urban Fine-grained Sediment Yields

228 Once development is complete, suspended sediment yields from established urban areas

229 remain higher than background levels, but much lower than during construction (Chin,

230 2006). Summarized suspended sediment yields from urban watersheds tend to fall between

2317 and 1,700 t/km²/yr, with a median of $240 \mathrm{t} / \mathrm{km}^{2} / \mathrm{yr}$, and are mostly 2-70 times higher than

232 background levels, with a median increase of around 6 times forest yields and 3 times

233 agricultural yields. In the Maryland Piedmont, suspended sediment yields from established

234 urban areas are around 1.7 times higher than rural areas, compared to active construction

235 sites which were 15 times higher (Fox, 1976). This is supported by a recent study in the

236 same region (Smith and Wilcock, 2015), which found that urban non-channel sources

237 remained elevated after development was established. Increases in established urban 
238 watershed sediment yields in tropical areas are similar to those in temperate areas,

239 estimated at twice background levels from forested watersheds in Tahiti (Wotling and

240 Bouvier, 2002) and 8-16 times background levels in Malaysia (Balamurugan, 1991;

241 Douglas, 1978; Wan Ruslan Ismail, 1997).

$242 \quad$ Urban Coarse-grained Sediment Yields

243 Impervious surfaces and storm drains in established urban areas can increase or decrease

244 bed load in urban streams (Bull and Scott, 1974). While these processes can limit the

245 available sediment by converting sediment-liberating headwater streams to underground

246 pipes, they can also increase sediment transport capacity (by increasing runoff and stream

247 flows), and efficiency of sediment transport pathways. While many have speculated that

248 coarse-grained sediment supply from non-channel sources should decrease due to sealing of

249 surfaces (Bledsoe and Watson, 2001; Gurnell et al., 2007; Hawley et al., 2013; Vietz et al.,

250 2014), observed decreases have not actually been documented, and a small number of

251 studies have documented or inferred increases in upland sediment supply (Pizzuto et al.,

252 2000; Smith and Wilcock, 2015).

253 In Maryland it was found that the coarse-grained (sand and gravel) sediment load of 90

$254 \mathrm{t} / \mathrm{km}^{2} / \mathrm{yr}$ from a fully suburban first-order basin was well in excess of estimates for

255 comparable forested basins from the same study, which yielded around $5-22 \mathrm{t} / \mathrm{km}^{2} / \mathrm{yr}$ of

256 coarse-grained sediment (Smith and Wilcock, 2015). In gravel bed rivers in Pennsylvania,

257 bedload transport remained significant after decades of urbanization, indicating that

258 channel erosion and hillslope sources were enough to maintain bed material sizes to near-

259 natural conditions (Pizzuto et al., 2000). 
260 A bedload yield of only $6.3 \mathrm{t} / \mathrm{km}^{2} / \mathrm{yr}$ was measured for an almost entirely urbanized

261 watershed in Tennessee (Grable, 2003). While background rates were not reported, this is

262 fairly low compared to measurements from the mid-Atlantic piedmont (Smith and Wilcock,

263 2015), but still higher than suspended loads (and hence probably much higher than

264 bedloads) for forested areas in Kentucky (Collier, 1962) and Maryland (Wolman, 1967).

265 Conceptual Model: Quantifying Sediment Yields in Urbanizing and Urban

$266 \quad$ Watersheds

267 The summarized findings of the literature spanning half a century since the model of

268 Wolman (1967) allow us to quantify sediment yield for land use changes from forest to

269 established urban (Fig. 2). Summarized rates of sediment yield from forested, agricultural

270 and urban construction phases from the literature over the last 50 years correspond well

271 with the model of Wolman, which sits within the middle two quartiles of the summarized

272 data. Wolman's postulated urban sediment yield, however, sits at the lower end of the

273 range of summarized yields, and the speculation that post-urbanization sediment yields

274 decline to levels as low as or lower than background levels is generally not supported by

275 subsequent empirical studies. While there is a great degree of variability in yields across all

276 land uses (2-3 orders of magnitude), the compiled data indicate that measured urban

277 sediment yields tend to remain around 3 times higher than yields from rural watersheds and

278 around 6 times higher than yields from forested watersheds.

279 Sediment yield is likely to increase by around an order of magnitude when a watershed is

280 converted from forested to rural land use, then by another order of magnitude during

281 urbanization when there are significant levels of active construction in the watershed. After 
282 establishment of urban areas, sediment yields are likely to decline but still remain much

283 higher than background levels. The summarized data is based on suspended sediment and

284 total sediment yields, and the pattern may be different for coarse-grained sediment yields.

285 The high sediment yields in established urban areas may be partially explained by the

286 relatively few studies which capture genuinely established conditions (where the river

287 system has adjusted fully to the new hydrologic and sediment input conditions). Given that

288 this adjustment can take more than 50 years areas (Chin, 2006), it is likely that some of the

289 watersheds that are identified as fully urbanized have channels that are still adjusting with

290 elevated rates of channel erosion contributing to high sediment yields. The extent to which

291 infill development and urban renewal keeps altering watershed hydrology and sediment

292 regimes is also difficult to discern from studies. 


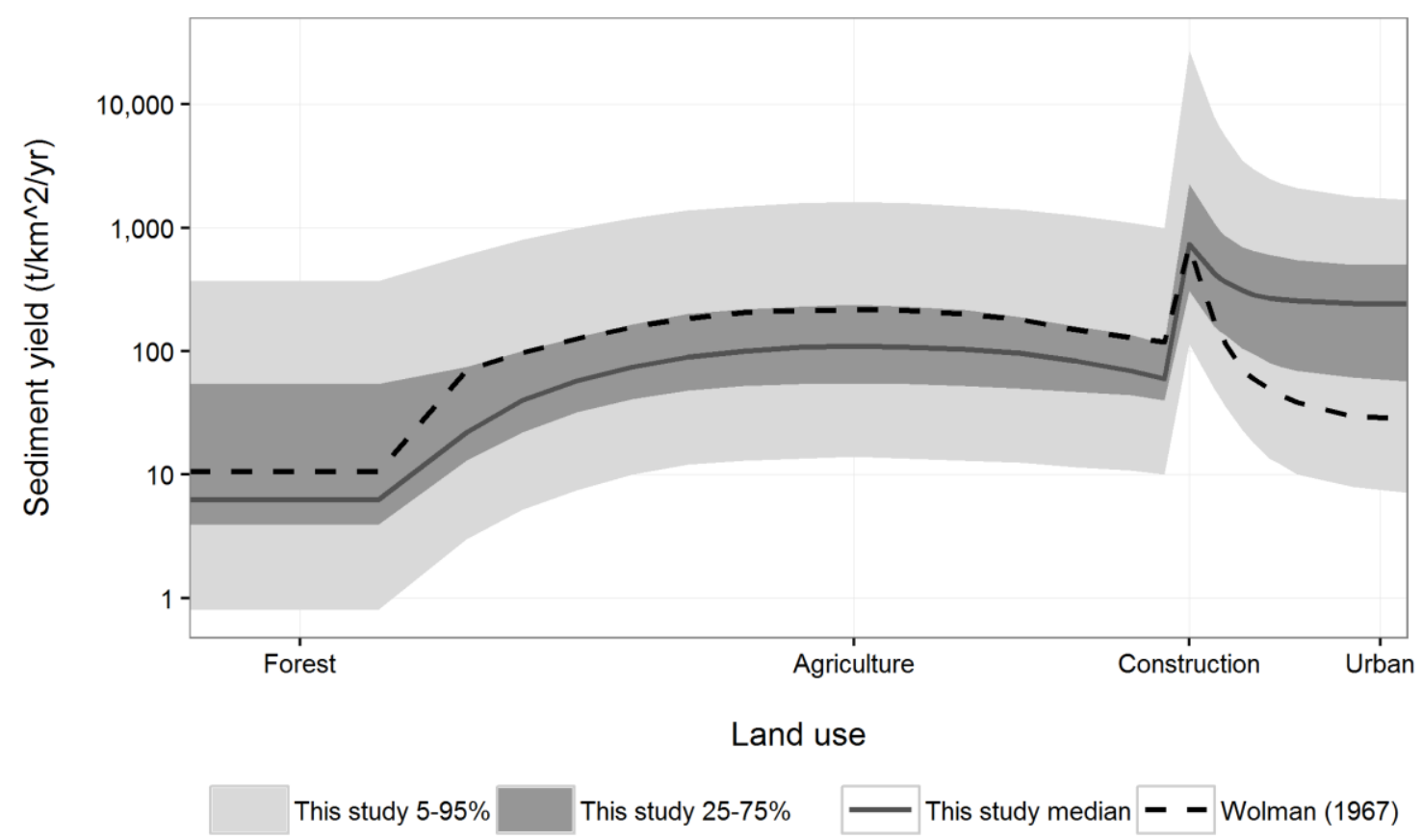

295 Fig. 2. Quartiles of summarized sediment yield data compared to the conceptual sediment 296 yield curve of Wolman (1967), digitized from the original.

297 Sources of Sediment in Urban Watersheds

298 Given that a large proportion of the land surface in urban watersheds is stabilized and 299 sealed, the higher sediment yield than background levels raises the question of where the 300 elevated sediment loads may be coming from.

301 A major and widely-documented sediment source is channel erosion, which is a common 302 response to altered urban flow conditions (Chin, 2006), and can supply excess sediment to 303 downstream areas. A notable example is San Diego Creek in southern California, where 304 stream channel erosion provided around $70 \%$ of the sediment yield at the point of 305 observation (Trimble, 1997). This was measured over a period of active urbanization in the 
306 watershed, however stream channel erosion can persist long after establishment of urban

307 land use (Chin, 2006).

308 Other sources include sediment from sealed and unsealed roads and imported,

309 anthropogenic particles. In particular, gravel roads or roads with gravel shoulders can

310 produce significant sediment loads on the same order of magnitude as construction sites.

311 The supply of sediment from these areas is effectively unlimited, as they tend to be repaired

312 by adding sediment sourced from external watersheds. Average fine-grained sediment

313 yields for gravel forest roads range from 150 to $166,000 \mathrm{t} / \mathrm{km}^{2} / \mathrm{yr}$, depending on level of

314 usage (Reid and Dunne, 1984) and have been estimated to be 4-8 times higher than

315 background erosion rates in similar settings (Fahey and Coker, 1992). Gravel roads and

316 gravel-shouldered roads tend to be a feature of peri-urban and lower density areas rather

317 than inner-urban areas, but gravel surfaces in house yards, parks and gardens are common

318 even in medium to high-density urban areas. Unpaved road sources provide around $15 \%$ of

319 the urban sediment yield in suburban Brasilia, despite covering only a small portion of the

$320 \quad$ area (Franz et al., 2014).

321 Runoff from sealed roads can also deliver road-deposited sediment (RDS) to waterways.

322 RDS is generally fine-grained in caliber (mostly less than $1 \mathrm{~mm}$ ), and runoff from sealed

323 roads preferentially transports only the finer fractions of RDS (Zhao et al., 2010), however,

324 one study has found that particles larger than $1 \mathrm{~mm}$ account for up to $35 \%$ of the sediment

325 load in road runoff (Kim and Sansalone, 2008). RDS yields are similar to general urban

326 sources at around $50 \mathrm{t} / \mathrm{km}^{2} / \mathrm{yr}$ (Mar et al., 1982). 
327 Urban areas can also be a significant source of anthropogenic particles (riprap, concrete, 328 asphalt, glass, brick etc.) to streams, supplementing the coarse sediment loading to urban 329 streams. These particles can make up a significant proportion of bed sediment (2-21\% of 330 particles), and are generally coarser than natural sediment particles (Grable and Harden, 331 2006; Grable, 2003).

332 It is also important to note that construction is never fully complete in an urban catchment 333 with decay, renewal, infill development and landscaping constantly occurring. Given that

334 sediment yields from construction areas tend to be around 50 times higher than from 335 agricultural areas and 700 times higher than from forested areas, even a small amount of 336 renewal or infill development could supply a significant amount of sediment and produce 337 an overall increase over background conditions.

\section{$338 \quad$ Influence of Stormwater Design and Sediment Control Measures}

339 Sediment yields from urbanizing and established watersheds also depend on local 340 stormwater design arrangements. For example, sediment control measures are usually 341 required by environmental and planning authorities at construction sites. Sediment control 342 measures are highly effective when applied correctly (Benik, 2003), however given that 343 construction increases sediment loads up to 300-fold, and commonly more than 10-fold, 344 removal efficiencies need to be very high to mitigate to background levels. In addition, 345 poor design, compliance and maintenance are commonplace (Hogan et al., 2014; Kaufman, 346 2000), and can lead to failure of sediment control measures.

347 After establishment of urban land cover, infrastructure used to remove sediment from 348 runoff may actually deplete sediment loads to below pre-urbanization levels. Depending on 
349 design and bypass arrangements, stormwater treatment measures such as gully pots, gross

350 pollutant traps, sediment ponds and check dams can form a complete barrier to coarse-

351 grained sediment supply (Butler and Karunaratne, 1995; Houshmand et al., 2014). Non-

352 complete barriers such as grassed filter strips and swales can also trap a significant

353 proportion of the coarse sediment load (Deletic, 2005). Sediment loads in urban streams,

354 particularly coarse-sediment loads, are therefore greatly influenced by the design of

355 sediment trapping measures and stormwater systems. The interruption of coarse sediment

356 supply is a harmful by-product of such efforts to decrease fine sediment and nutrient inputs

357 to streams, which can exacerbate channel instability and degradation (Vietz et al., 2016).

$358 \quad$ Factors Contributing to Variability

359 The collated sediment yields for all land use categories show great variability (by 2-3

360 orders of magnitude), even at a given watershed area or location. The high levels of

361 variability illustrate the complexity of sediment yield quantification and the difficulty of

362 making comparisons between urban and non-urban watersheds using space-for-time

$363 \quad$ substitution methods.

364 Climate significantly influences variability in sediment yield. Sediment yields tend to be

365 higher in tropical areas (Wasson et al., 1996) due to increased runoff, and may also be

366 higher in very arid areas than semi-arid and temperate climates, where the amount of runoff

367 is adequate to erode material, but not to encourage growth of protective vegetation

368 (Douglas, 1967; Langbein and Schumm, 1958). In New Zealand, where rainfall is highly

$369 \quad$ variable, a strong relationship between sediment yield and annual rainfall has been 
370 observed (Griffiths, 1981). Such relationships are highly localized depending on climate

371 regime (Wilson, 1973) and vegetation type (Dunne, 1979).

372 Suspended sediment yield also depends on watershed area and relief, typically decreasing 373 with increasing watershed area due to lower slope gradients reducing sediment liberation

374 and transport. There is also increased sediment storage on the lower slopes, channels and

375 floodplains in flatter catchments (Walling, 1983). This trend is discernable in the sediment

376 yields collated for construction areas, but not in the data for forest, agricultural or urban

377 areas. For construction areas, the trend is partly driven by a dilution effect (Wolman and

378 Schick, 1967) whereby larger watersheds tend to have only part of the area under

379 construction at any one time, whereas the smaller watersheds being monitored are under

380 intensive construction. However even when considering only the yields reported for areas

381 completely under construction, yields still appear to decline with increasing watershed area,

382 which may indicate a negative relationship between watershed area and slope. Watershed

383 slope is an important driver of sediment yield (given its primary role in sediment transport),

384 however, perhaps surprisingly, it was not reported in an adequate number of studies or with

385 a level of consistency that would allow for broad comparisons.

386 As well as the question of watershed area, the relative scale of urbanization and the spatial 387 organization of urban areas within a watershed are important variables that drive sediment

388 yield. Most studies are undertaken on small watersheds with relatively homogeneous land

389 uses, but the impact of cities on large rivers (given that cities tend to be located at the

390 outlets of large, mixed-use watersheds) also requires further investigation. 
The highly variable effects of urbanization on the sediment regimes of rivers can lead to complex responses in stream health. While it is known that watershed urbanization consistently causes ecological and geomorphic degradation of streams (Walsh et al., 2005a; Wenger et al., 2009), it is difficult to disentangle the influences of flow regime disturbance and sediment regime disturbance. Sediment regime changes often co-vary with flow regime changes in urbanizing areas, so the effects of each are particularly difficult to differentiate. Stream response to urbanization also depends on past land uses in the watershed and direct channel interventions such as channel stabilization (Vietz et al., 2016).

Increases in the delivery of fine-grained sediments from urbanizing watersheds to streams can decrease bed sediment size (Booth and Jackson, 1997), or increase smothering of the channel bed (Fox, 1976; Wolman, 1967; Wolman and Schick, 1967). Excessive finegrained sediment input from construction and channel erosion sources reduces primary production and has deleterious impacts on macroinvertebrates and fish reliant on benthic habitat (Mebane, 2001; Wood and Armitage, 1997). Suspended sediment in the water column impacts on fish (Walters et al., 2009) and filter feeders such as mussels (Wood and Armitage, 1997). Increased delivery of sediment associated nutrients and contaminants (such as heavy metals) causes eutrophication in receiving waters, toxicity to aquatic life and detrimental effects to human health (Owens et al., 2005). While channel contraction is common downstream of construction areas (Leopold et al., 2005; Wolman, 1967; Wolman and Schick, 1967), channel widening (Chin and Gregory, 2001; Fox, 1976) and planform changes (Hawley et al., 2012) have also been observed. 
413 After establishment of urban areas, increases in sediment transport capacity are likely to

414 produce channel incision (deepening and widening), loss of bed features (Vietz, 2013), and

415 bed coarsening as finer sediments are preferentially removed (Finkenbine et al., 2000;

416 Hawley et al., 2013). Even if the sediment supply remains higher than background levels,

417 the greatly increased flow energy is likely to dominate the flow-sediment balance. This

418 maintains reduced depths of mobile bed sediments and results in long-term reductions in

419 channel complexity and the hydraulic and sedimentologic heterogeneity required for

420 healthy ecological habitats (Vietz et al., 2014).

421 Sedimentation impacts associated with early stages of construction are transient in nature

422 (Fox, 1976), however the time period required for excess sediment to be flushed from the

423 system can vary from 5 to 50 years (Chin, 2006), and the time required for the stream to

424 adjust to the new flow regime can be even longer. Therefore sedimentation impacts from

425 urban development may persist long after the urban watershed is established.

426 A future management challenge will be to continue to mitigate urban hydrologic

427 disturbance and minimize stormwater pollution, while maintaining coarse-grained sediment

428 supply to streams (Fletcher et al., 2014) at rates consistent with natural, pre-developed

429 levels. In systems where coarse-grained sediments are currently being trapped in

430 stormwater control measures such as basins, gross pollutant traps, and wetlands, coarse-

431 grained sediment fractions can be redirected into the stream, reducing maintenance costs

432 and improving stream condition (Houshmand et al., 2014). Sediment replenishment

433 downstream of dams has been trialed with some success (Merz et al., 2005; Zeug et al.,

434 2014). The replenishment method must be tailored to the post-disturbance flow regime 
435 (Ock et al., 2013), which will be particularly important under a highly modified post-urban 436 flow regime.

437 The need to continue to reduce fine-grained sediment delivery to channels to protect 438 streams and receiving waters from water quality impacts, while maintaining ecologically439 important coarse sediment loads, is a major design challenge for the future of stormwater 440 management. However, opportunities exist to reduce the sediment maintenance in 441 stormwater control measures by bypassing or redirecting coarse-grained sediment, as 442 trialed in a recent pilot study in south-eastern Australia (Houshmand et al., 2014).

443 Research is required to investigate the implications of sediment yield changes from urban 444 and urbanizing watersheds on the physical and ecological condition of receiving streams. If 445 altered sediment inputs are a significant driver of urban stream degradation then 446 opportunities for better management of sediments in stormwater systems require field 447 testing at a watershed, street and plot scale. In particular, standardizing the way in which $448 \quad$ studies on sediment yields are undertaken and reported will assist in improving our 449 understanding of a 'common' response of sediment yield to urbanization of a watershed. $450 \quad$ For example, this could include ensuring details of land cover and land use, and 451 background factors such as watershed slope, rainfall, and natural vegetation type, are 452 consistently reported, and that these background factors are controlled as much as possible 453 when using space-for-time substitution.

454 Improved understanding and management of sediment from urbanizing and established 455 urban watersheds will assist in moving beyond the common urban stream management 456 philosophy of imposing channel morphology towards one that seeks to preserve natural 
457 watershed processes where possible (Wohl et al., 2015). In this 'stream accommodation'

458 approach to waterway management, appropriate flow and sediment regimes would be

459 maintained by urban stormwater management and protection of coarse-grained sediment

460 sources, and adequate space would be provided for the stream to remain self-adjusting

461 (Vietz et al., 2016). While progress has been made towards implementing this kind of

462 approach to the hydrology of urban watersheds, attempts to restore or preserve stream

463 ecosystems will likely be limited if the sediment regime disturbance is not better

$464 \quad$ understood and addressed.

\section{$465 \quad$ Conclusion}

466 The reported sediment yields from urbanizing and urban watersheds collated and 467 summarized for this study have demonstrated that suspended and total sediment yields are

468 likely to greatly increase in watersheds under urbanization, then decline, but remain

469 elevated above background conditions once fully urban land cover is established. While

470 these findings have, in many respects, validated the model suggested by Wolman (1967),

471 evidence from the literature suggest that Wolman's speculation that fully urban watersheds

472 would have sediment yields lower than background levels is incorrect. While urban land

473 cover locks up some sediment sources, other sediment sources are introduced, such as

474 construction for infill development, gravel landscaping surfaces and road deposited

475 sediments. These sources are easily eroded by high-energy urban runoff and are transported

476 to streams via efficient urban drainage systems. The summarized data was predominantly

477 based on measurements of suspended yield or total yield, with very little data on bedload

478 yield in urbanizing and urban watersheds. The pattern for coarse-grained sediment, which is 
479 of great importance in maintaining stability and ecological health of streams, may be

480 different. In any case, the urban flow regime appears to produce increases in sediment

481 transport capacity that overwhelm any increase in sediment supply, causing channel erosion

482 and loss of bed sediment and habitat complexity. Efforts to address the urban flow problem

483 will need to be sensitive to the need to maintain coarse-grained sediment supply to the

484 channel, potentially using bypass or supplementation arrangements. In the long term,

485 efforts need to be made to preserve the natural function of catchments and stream corridors

486 in urban areas, maintaining runoff and sediment supply as close as possible to background

487 conditions, and allowing streams room to move and adjust.

$488 \quad$ Acknowledgments

489 The data reported in the paper are presented in the Supplementary Materials. This work was

490 funded by an Australian Postgraduate Award scholarship and the Melbourne Waterway

491 Research Practice Partnership (http://mwrpp.org). Fletcher was supported by the

492 Australian Research Council (FT100100144) during part of this study. The funding sources

493 had no direct involvement in the study.

\section{$494 \quad$ References}

495

496

497

498

499

500

501

502

503

504
Ackers, P. and White, W.R., 1973. Sediment transport: new approach and analysis. Journal of the Hydraulics Division, 99(hy11): 204-254.

Balamurugan, G., 1991. Tin mining and sediment supply in Peninsular Malaysia with special reference to the Kelang River basin. Environmentalist, 11(4): 281-291.

Benik, S.R., 2003. Performance of erosion control products on a highway embankment. Transactions of the ASAE, 46(4): 1113.

Bledsoe, B.P. and Watson, C.C., 2001. Effects of Urbanization on Channel Instability. Journal of the American Water Resources Association, 37(2): 255-270.

Booth, D.B., 1991. Urbanization and the natural drainage system--impacts, solutions, and prognoses. The Northwest Environmental Journal, 7: 93-118. 
Booth, D.B. and Jackson, C.R., 1997. Urbanization of Aquatic Systems: Degradation Thresholds, Stormwater Detection, and the Limits of Mitigation. Journal of the American Water Resources Association, 33(5): 1077-1090.

Bull, W.B. and Scott, K.M., 1974. Impact of mining gravel from urban stream beds in the southwestern United States. Geology, 2(4): 171-174.

Butler, D. and Karunaratne, S., 1995. The suspended solids trap efficiency of the roadside gully pot. Water research, 29(2): 719-729.

Chin, A., 2006. Urban transformation of river landscapes in a global context. Geomorphology, 79(3-4): 460-487.

Chin, A. and Gregory, K.J., 2001. Urbanization and adjustment of ephemeral stream channels. Annals of the Association of American Geographers, 91(4): 595-608.

Collier, C.R., 1962. Influence of strip mining on the hydrologic environment of parts of Beaver Creek basin, Kentucky, 1955-1959, U. S. Geological Survey, Washington.

Croke, J. and Hairsine, P., 2006. Sediment delivery in managed forests: a review. Environmental Reviews, 14(1): 59-87.

Dearing, J.A., Elner, J.K. and Happey-Wood, C.M., 1981. Recent sediment flux and erosional processes in a Welsh upland lake-catchment based on magnetic susceptibility measurements. Quaternary Research, 16: 356-372.

Deletic, A., 2005. Sediment transport in urban runoff over grassed areas. Journal of Hydrology, 301(1-4): 108-122.

Douglas, I., 1967. Man, vegetation and the sediment yields of rivers. Nature, 215: 925-928.

Douglas, I., 1978. The impact of urbanization on fluvial geomorphology in the humid tropics. GeoEco-Trop, 2(23): 242.

Dunne, T., 1979. Sediment yield and land use in tropical catchments. Journal of Hydrology, 42(34): 281-300.

Fahey, B.D. and Coker, R.J., 1992. Sediment production from forest roads in Queen Charlotte Forest and potential impact on marine water quality, Marlborough Sounds, New Zealand. New Zealand Journal of Marine and Freshwater Research, 26(2): 187-195.

Finkenbine, J., Atwater, J. and Mavinic, D., 2000. Stream Health After Urbanization. Journal of the American Water Resources Association, 36(5): 1149-1160.

Fletcher, T.D., Vietz, G. and Walsh, C.J., 2014. Protection of stream ecosystems from urban stormwater runoff The multiple benefits of an ecohydrological approach. Progress in Physical Geography, 38(5): 543-555.

Foster, I., Dearing, J. and Appleby, P., 1986. Historical trends in catchment sediment yields: a case study in reconstruction from lake-sediment records in Warwickshire, UK. Hydrological sciences journal, 31(3): 427-443.

Foster, I. and Walling, D., 1994. Using reservoir deposits to reconstruct changing sediment yields and sources in the catchment of the Old Mill Reservoir, South Devon, UK, over the past 50 years. Hydrological Sciences Journal, 39(4): 347-368.

Foster, I.D.L., Dearing, J.A., Simpson, A., Carter, A.D. and Appleby, P.G., 1985. Lake catchment based studies of erosion and denudation in the merevale catchment, Warwickshire, U.K. Earth surface processes and landforms, 10(1): 45-68.

Fox, H.L., 1976. The urbanizing river: a case study in the Maryland Piedmont. In: D.R. Coates (Editor), Geomorphology and Engineering: Proceedings of the Seventh Annual Geomorphology Symposium held at Binghampton, Sept 24-25, 1976. Dowden, Hutchinson and Ross, Inc., pp. 245-271. 
Franz, C., Makeschin, F., Weiß, H. and Lorz, C., 2014. Sediments in urban river basins: Identification of sediment sources within the Lago Paranoa catchment, Brasilia DF, Brazil-using the fingerprint approach. Science of the Total Environment, 466: 513-523.

Grable, J. and Harden, C.P., 2006. Geomorphic response of an Appalachian Valley and Ridge stream to urbanization. Earth Surface Processes and Landforms, 31(13): 1707-1720.

Grable, J.L., 2003. Effects of Urbanization on a Small Perennial Stream: Second Creek in Knoxville, Tennessee. Thesis Thesis, University of Tennessee.

Graf, W.L., 1975. The impact of suburbanization on fluvial geomorphology. Water Resources Research, 11(5): 690-692.

Griffiths, G.A., 1981. Some Suspended Sediment Yields from South Island Catchments, New Zealand. Journal of the American Water Resources Association, 17(4): 662-671.

Gurnell, A., Lee, M. and Souch, C., 2007. Urban rivers: hydrology, geomorphology, ecology and opportunities for change. Geography Compass, 1(5): 1118-1137.

Guy, H.P., 1970. Sediment problems in urban areas. 2330-5703, U. S. Geological Survey, Washington.

Guy, H.P., 1974. Remote sensing techniques for evaluation of urban erosion and sedimentation, Effects of Man on the Interface of the Hydrological Cycle with the Physical Environment [Proceedings of the Paris Symposium, September 1974]. IAHS Pub. no. 113, pp. 145-149.

Hammer, T.R., 1972. Stream channel enlargement due to urbanization. Water Resources Research, 8(6): 1530-1540.

Hawley, R.J., Bledsoe, B.P., Stein, E.D. and Haines, B.E., 2012. Channel Evolution Model of Semiarid Stream Response to Urban-Induced Hydromodification1. Journal of the American Water Resources Association, 48(4): 722-744.

Hawley, R.J., MacMannis, K.R. and Wooten, M.S., 2013. Bed coarsening, riffle shortening, and channel enlargement in urbanizing watersheds, northern Kentucky, USA. Geomorphology, 201(0): 111-126.

Hawley, R.J. and Vietz, G.J., 2016. Addressing the urban stream disturbance regime. Freshwater Science, 35(1).

Hogan, D.M., Jarnagin, S.T., Loperfido, J. and Ness, K., 2014. Mitigating the effects of landscape development on streams in urbanizing watersheds. Journal of the American Water Resources Association, 50(1): 163-178.

Holeman, J.N., 1965. Sedimentation of Loch Raven and Prettyboy Reservoirs, Baltimore County, Maryland. US Dept. Agric. SCS-TP, 145: 17.

Houshmand, A., Vietz, G.J. and Hatt, B.E., 2014. Improving Urban Stream Condition by Redirecting Sediments: A Review of Associated Contaminants. In: G.J. Vietz, I.D. Rutherfurd and R.M. Hughes (Editors), Proceedings of the 7th Australian Stream Management conference, Townsville, Australia, pp. 549-557.

Kaufman, M.M., 2000. Erosion control at construction sites: the science-policy gap. Environmental Management, 26(1): 89-97.

Kim, J.-Y. and Sansalone, J.J., 2008. Event-based size distributions of particulate matter transported during urban rainfall-runoff events. Water research, 42(10): 2756-2768.

Langbein, W.B. and Schumm, S.A., 1958. Yield of sediment in relation to mean annual precipitation. EOS, Transactions, American Geophysical Union, 39(6): 1076-1084.

Leigh, C.H., 1982. Urban development and soil erosion in Kuala Lumpur, Maylaysia. Journal of environmental management, 15: 33-45. 
Leopold, L.B., Huppman, R. and Miller, A., 2005. Geomorphic effects of urbanization in forty-one years of observation. Proceedings of the American Philosophical Society: 349-371.

Mackin, J.H., 1948. Concept of the graded river. Geological Society of America Bulletin, 59(5): 463512.

Mar, B., Horner, R., Ferguson, J., Spyridakis, D. and Welch, E., 1982. Summary - Highway Runoff Water Quality Study, 1977-1982, Washington State Dept. of Transportation, Olympia, WA.

Mebane, C.A., 2001. Testing bioassessment metrics: macroinvertebrate, sculpin, and salmonid responses to stream habitat, sediment, and metals. Environmental Monitoring and Assessment, 67(3): 293-322.

Merz, J.E., Chan, O. and Leigh, K., 2005. Effects of gravel augmentation on macroinvertebrate assemblages in a regulated California river. River Research and Applications, 21(1): 61-74.

Milliman, J.D. and Meade, R.H., 1983. World-wide delivery of river sediment to the oceans. Journal of Geology, 91(1): 1-21.

Milliman, J.D. and Syvitski, J.P., 1992. Geomorphic/tectonic control of sediment discharge to the ocean: the importance of small mountainous rivers. Journal of Geology: 525-544.

Nelson, E.J. and Booth, D.B., 2002. Sediment sources in an urbanizing, mixed land-use watershed. Journal of Hydrology, 264(1): 51-68.

Nishimune, S.-i., Onodera, T., Naruoka, M.D. and Birmano, 2003. Comparative study of bedload sediment yield processes in small mountainous catchments covered by secondary and disturbed forests, western Japan. Hydrobiologia, 494(1-3): 265-270.

Noske, P.J., Lane, P.N. and Sheridan, G.J., 2010. Stream exports of coarse matter and phosphorus following wildfire in NE Victoria, Australia. Hydrological processes, 24(11): 1514-1529.

O'Driscoll, M., Clinton, S., Jefferson, A., Manda, A. and McMillan, S., 2010. Urbanization effects on watershed hydrology and in-stream processes in the southern United States. Water, 2(3): 605-648.

Ock, G., Sumi, T. and Takemon, Y., 2013. Sediment replenishment to downstream reaches below dams: implementation perspectives. Hydrological Research Letters, 7(3): 54-59.

Owens, P., Batalla, R., Collins, A., Gomez, B., Hicks, D., Horowitz, A., Kondolf, G., Marden, M., Page, M. and Peacock, D., 2005. Fine-grained sediment in river systems: environmental significance and management issues. River Research and Applications, 21(7): 693-717.

Palmer, M., Allan, J.D., Meyer, J. and Bernhardt, E.S., 2007. River restoration in the twenty-first century: data and experiential knowledge to inform future efforts. Restoration Ecology, 15(3): 472-481.

Papworth, M., Hartland, R. and Lucas, A., 1990. Logging Alpine Ash in the East Kiewa River Catchment. Part I: Effects on Stream Sediment Levels, Department of Conservation and Environment, Land Protection Division, Hydrology Section.

Paul, M.J. and Meyer, J.L., 2001. Streams in the urban landscape. Annual Review of Ecology and Systematics, 32: 333-365.

Petts, G.E. and Gurnell, A.M., 2005. Dams and geomorphology: research progress and future directions. Geomorphology, 71(1): 27-47.

Pizzuto, J., Hession, W. and McBride, M., 2000. Comparing gravel-bed rivers in paired urban and rural catchments of southeastern Pennsylvania. Geology, 28(1): 79-82.

Reid, L.M. and Dunne, T., 1984. Sediment production from forest road surfaces. Water Resources Research, 20(11): 1753-1761. 
Schiefer, E., Hassan, M.A., Menounos, B., Pelpola, C.P. and Slaymaker, O., 2010. Interdecadal patterns of total sediment yield from a montane catchment, southern Coast Mountains, British Columbia, Canada. Geomorphology, 118(1): 207-212.

Smith, S. and Wilcock, P., 2015. Upland sediment supply and its relation to watershed sediment delivery in the contemporary mid-Atlantic Piedmont (USA). Geomorphology, 232: 33-46.

Taylor, K.G. and Owens, P.N., 2009. Sediments in urban river basins: a review of sedimentcontaminant dynamics in an environmental system conditioned by human activities. Journal of Soils and Sediments, 9(4): 281-303.

The World Bank, 2014. World Bank Open Data: Urban population (\% of total) and Urban population growth (annual \%).

Trimble, S.W., 1997. Contribution of stream channel erosion to sediment yield from an urbanizing watershed. Science, 278(5342): 1442-1444.

Vaze, J. and Chiew, F.H., 2004. Nutrient loads associated with different sediment sizes in urban stormwater and surface pollutants. Journal of Environmental Engineering, 130(4): 391396.

Vietz, G., 2013. Water (way) sensitive urban design: Addressing the causes of channel degradation through catchment-scale management of water and sediment, Proceedings of the 8th International Water Sensitive Urban Design Conference. Engineers Australia, Gold Coast, Australia.

Vietz, G.J., Rutherfurd, I.D., Fletcher, T.D. and Walsh, C.J., 2016. Thinking outside the channel: Challenges and opportunities for protection and restoration of stream morphology in urbanizing catchments. Landscape and Urban Planning, 145: 34-44.

Vietz, G.J., Sammonds, M.J., Walsh, C.J., Fletcher, T.D., Rutherfurd, I.D. and Stewardson, M.J., 2014. Ecologically relevant geomorphic attributes of streams are impaired by even low levels of watershed effective imperviousness. Geomorphology, 206: 67-78.

Vietz, G.J., Walsh, C.J. and Fletcher, T.D., 2015. Urban hydrogeomorphology and the urban stream syndrome: Treating the symptoms and causes of geomorphic change. Progress in Physical Geography, 40(3): 480-492.

Walling, D., 1983. The sediment delivery problem. Journal of hydrology, 65(1): 209-237.

Walsh, C.J., Fletcher, T.D. and Ladson, A.R., 2005a. Stream restoration in urban catchments through redesigning stormwater systems: looking to the catchment to save the stream. Journal of the North American Benthological Society, 24(3): 690-705.

Walsh, C.J., Roy, A.H., Feminella, J.W., Cottingham, P.D., Groffman, P.M. and Morgan, R.P., 2005b. The urban stream syndrome: current knowledge and the search for a cure. Journal of the North American Benthological Society, 24(3): 706-723.

Walters, D., Roy, A. and Leigh, D., 2009. Environmental indicators of macroinvertebrate and fish assemblage integrity in urbanizing watersheds. Ecological Indicators, 9(6): 1222-1233.

Wan Ruslan Ismail, 1997. The impact of hill land clearance and urbanization on runoff and sediment yield of small catchments in Pulau Pinang, Malaysia. In: D.E. Walling and J.-L. Probst (Editors), Human Impact on Erosion and Sedimentation [Proceedings of Rabat Symposium S6, April 1997]. IAHS Pub. no. 245, pp. 91-100.

Wasson, R., Olive, L. and Rosewell, C., 1996. Rates of erosion and sediment transport in Australia. In: D.E. Walling and B.W. Webb (Editors), Erosion and Sediment Yield: Global and Regional Perspectives: Proceedings of an International Symposium, Exeter, UK, from 15 to 19 July 1996. IAHS Pub. no. 236, pp. 139-148. 
Wenger, S.J., Roy, A.H., Jackson, C.R., Bernhardt, E.S., Carter, T.L., Filoso, S., Gibson, A.C., Hession, W.C., Kaushal, S.S., Marti, E., Meyer, J.L., Palmer, M.A., Paul, M.J., Purcell, A.H., Ramirez, A., Rosemond, A.D., Schofield, K.A., Sudduth, E.B. and Walsh, C.J., 2009. Twenty-six key research questions in urban stream ecology: an assessment of the state of the science. $\mathrm{N}$. Am. Benthol. Soc., 28(4): 1080-1098.

Wentworth, C.K., 1922. A scale of grade and class terms for clastic sediments. Journal of Geology, 30(5): 377-392.

Wilson, L., 1973. Variations in mean annual sediment yield as a function of mean annual precipitation. American Journal of Science, 273(4): 335-349.

Wohl, E., Bledsoe, B.P., Jacobson, R.B., Poff, N.L., Rathburn, S.L., Walters, D.M. and Wilcox, A.C., 2015. The natural sediment regime in rivers: Broadening the foundation for ecosystem management. BioScience, 65(4): 358-371.

Wolman, M.G., 1967. A cycle of sedimentation and erosion in urban river channels. Geografiska Annaler Series A Physical Geography, 49(2-4): 385-395.

Wolman, M.G. and Schick, A.P., 1967. Effects of construction on fluvial sediment, urban and suburban areas of Maryland. Water Resources Research, 3(2): 451-464.

Wood, P.J. and Armitage, P.D., 1997. Biological Effects of Fine Sediment in the Lotic Environment. Environmental management, 21(2): 203-217.

Wotling, G. and Bouvier, C., 2002. Impact of urbanization on suspended sediment and organic matter fluxes from small catchments in Tahiti. Hydrological processes, 16(9): 1745-1756.

Wu, A.Y.K., Papworth, M.P. and Flinn, D.W. (Editors), 1984. The effects of some forest practices on water quality and yield in the Reefton experimental area, Victoria. Part 1, pre-treatment phase. Soil Conservation Authority Hydrology Section.

Yorke, T.H. and Herb, W.J., 1978. Effects of urbanization on streamflow and sediment transport in the Rock Creek and Anacostia River Basins, Montgomery County, Maryland, 1962-74, U. S. Geological Survey, Washington.

Zeug, S., Sellheim, K., Watry, C., Rook, B., Hannon, J., Zimmerman, J., Cox, D. and Merz, J., 2014. Gravel augmentation increases spawning utilization by anadromous salmonids: a case study from California, USA. River research and applications, 30(6): 707-718.

Zhao, H., Li, X., Wang, X. and Tian, D., 2010. Grain size distribution of road-deposited sediment and its contribution to heavy metal pollution in urban runoff in Beijing, China. Journal of hazardous materials, 183(1): 203-210. 


\section{University Library}

\section{- M M N E R VA A gateway to Melbourne's research publications}

Minerva Access is the Institutional Repository of The University of Melbourne

Author/s:

Russell, KL;Vietz, GJ;Fletcher, TD

Title:

Global sediment yields from urban and urbanizing watersheds

Date:

2017-05-01

Citation:

Russell, K. L., Vietz, G. J. \& Fletcher, T. D. (2017). Global sediment yields from urban and urbanizing watersheds. EARTH-SCIENCE REVIEWS, 168, pp.73-80. https://doi.org/10.1016/ j.earscirev.2017.04.001.

Persistent Link:

http://hdl.handle.net/11343/288178 